\title{
Silurian graptolites from the Qusayba Shale (Llandovery) of central Saudi Arabia
}

\author{
A. A. EL-KHAYAL
}

\begin{abstract}
El-Khayal, A. A.: Silurian graptolites from the Qusayba Shale (Llandovery) of central Saudi Arabia. Bull. geol. Soc. Denmark, vol, 35, pp. 125-133. Copenhagen, July 1st, 1987. https://doi.org/10.37570/bgsd-1986-35-13

Graptolites of the Qusayba Shale, Al-Qasim Province, central Saudi Arabia, indicate a Llandovery age. Some species found are recorded for the first time and can be referred to species known from British and Bohemian beds. The assemblage includes Climacograptus cf. rectangularis, Climacograptus scalaris, Glyp-tograptus $(G)$ incertus, Orthograptus cyperoides, Orthograptus insectiformis, Petalograptus minor, P. ova-toelongatus, Retiolites perlatus perlatus, Pristiograptus regularis regularis, Lagarograptus cf. tenuis, Mono-graptus ex gr. barrandei, M. convolutus, M. decipiens decipiens, M. elongatus. The assemblage is indica-tive of the convolutus Zone.
\end{abstract}

El-Khayal, A. A., Geology Dept., P.O. Box 2455, King Saud University, Riyadh, 11451, Saudi Arabia. August 29th, 1985.

Silurian graptolites from the Tabuk Formation were first noted by Steineke et al. (1958) who mentioned that probable Climacograptus and several other graptolites serve as the basis for a Silurian assignment for beds about 375 metres below the top of Tabuk Formation. The Tabuk Formation was formally defined by Steineke et al. (1958).

Powers et al. (1966, p. D22) redefined the Tabuk Formation and mentioned (p. D24) that the most complete exposure of Tabuk beds south of the Great Nefud occurs in the Qusayba section, where three shale members within the section form roughly parallel escarpments near the top, middle and at the base. Using these shales as dividers, the Qusayba section can be separated into six informal units. These are from bottom up: 1 . Lower shale (Hanadir Member); 2. Lower sandstone; 3. Middle shale (Ra'an Member); 4. Middle sandstone; 5. Upper shale (Qusayba Member); 6. Upper sandstone. This work deals only with the Qusayba Member.

\section{Stratigraphy}

The Tabuk Formation is composed of a cyclic series of three graptolite-bearing shales alternating with continental marginal-marine sand units. Powers et al. (1966) dated the basal Tabuk For- mation (Hanadir shale) as Lower Ordovician (Arenig) on the basis of graptolites. Later workers, McClure (1978), Fortey and Morris (1982), and El-Khayal and Romano (1985) showed that the Hanadir Shale Member is of mainly Llanvirn age.

Powers et al. (1966, p. D25) mentioned that Diplograptus sp. and Climacograptus cf. C. brevis occur near the middle of the Tabuk Formation. McClure (1978) dated the Ra'an shales as probably of late Caradoc age, although an early Ashgill age cannot be ruled out. The writer recently collected some graptolites from the lower part of the Ra'an shale at Khashm al Ra'an near Qusayba. The graptolites were identified as $\mathrm{Or}$ thograptus amplexicaulus Hall.

According to Fairbridge (1970) and McClure (1978), the south pole and glacial epicentre were located in the vicinity of North West Africa. The northern margin of an extensive continental ice sheet apparently extended across about $4,000 \mathrm{~km}$ of North Africa. McClure, however, noted the presence of Upper Ordovician glaciated boulders and tillites in Saudi Arabia indicating that the vast ice sheet extended about $2,000 \mathrm{~km}$ further eastward. Uppermost Ordovician Ashgill beds have not been proved in the Qasim area.

The Qusayba shale sequence overlies the Middle crossbedded, light red and pale yellow medium granined sandstone containing Cruziana 


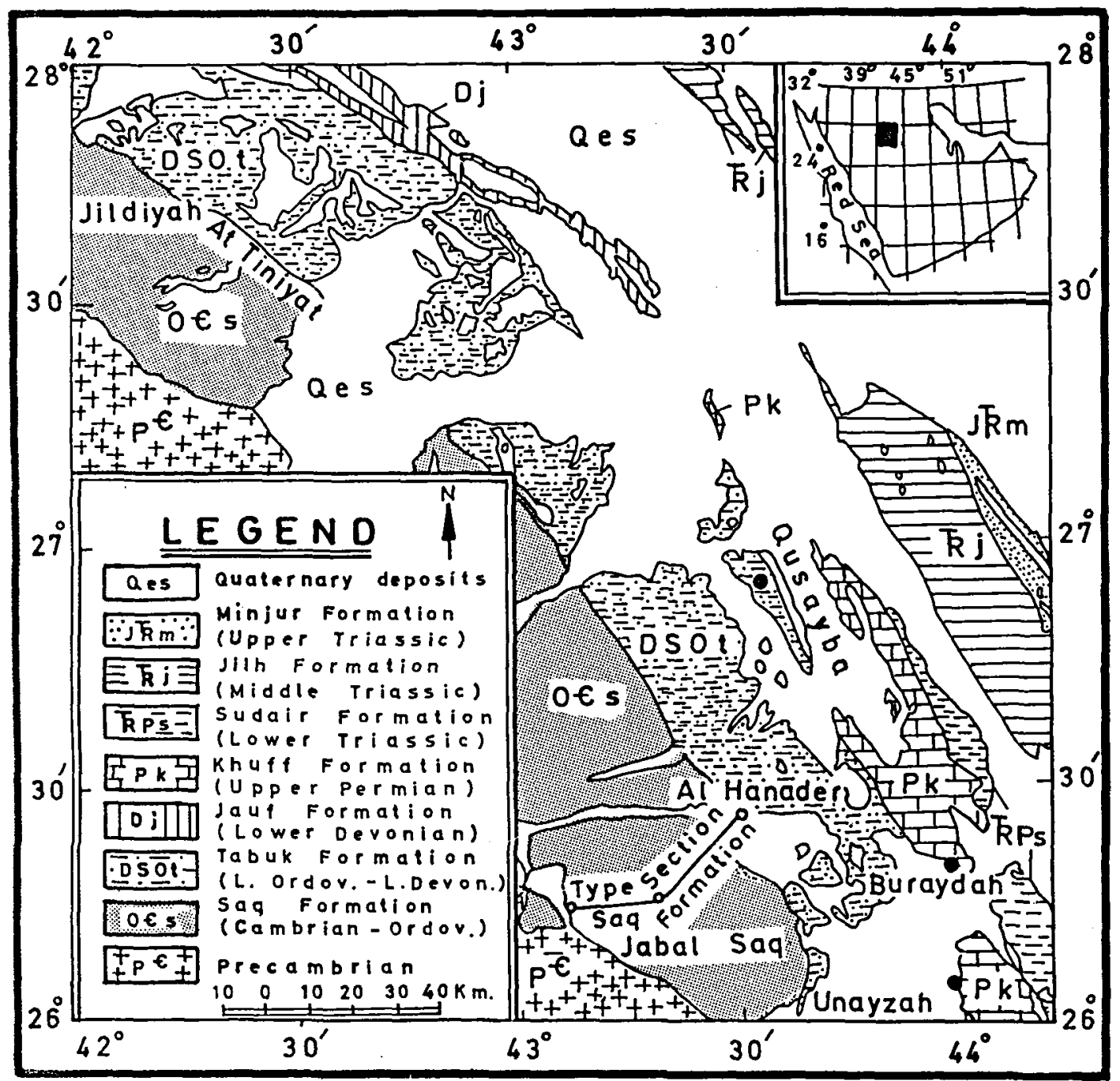

Fig. 1. Geological map of Al Qasim Province, Saudi Arabia. Showing Location of Qusayba village (From Bramkamp et al. 1963).

and Skolithos possibly of lower Silurian age (Rhuddanian stage of the Llandovery Series, because of its conformable stratigraphic position below the well dated Qusayba Shale Member (McClure, 1978).

The Qusayba Shale Member forms a vertical cliff facing east, at Al Qusayba, Al Qasim Province (Fig. 1), where 44 metres of mainly varicoloured shales are exposed. (Fig. 2). The unit thickens northwards. It is $126 \mathrm{~m}$ thick in the Jildiyah to Ashaybah section south of the Great Nefud (Powers et al. 1966, p. D113, sec. 4, unit 3).

The Qusayba Shale Member was originally measured in 1949 by Pocock and R. P. Kopp
(Fide Powers et al. 1966). The unit was described (op. cit., p. D113, sec. 3, unit 5) as follows: "Shale varicoloured, but mostly grey-green, laminated: more gypsiferous and with thin beds of red, hematitic siltstone in upper part; lower part is graptolitic. Poorly sorted grey medium-grained thin-bedded sandstone and highly weathered calcareous beds at top of unit, $57.4 \mathrm{~m}$."

No further details of these beds were given. The sequence is capped by highly weathered calcareous beds of Quaternary duricrust. The section at Qusayba may be correlated with the 47 metres described by Steineke et al. (1958) as grey, purple and green shale, in part silty and mi- 


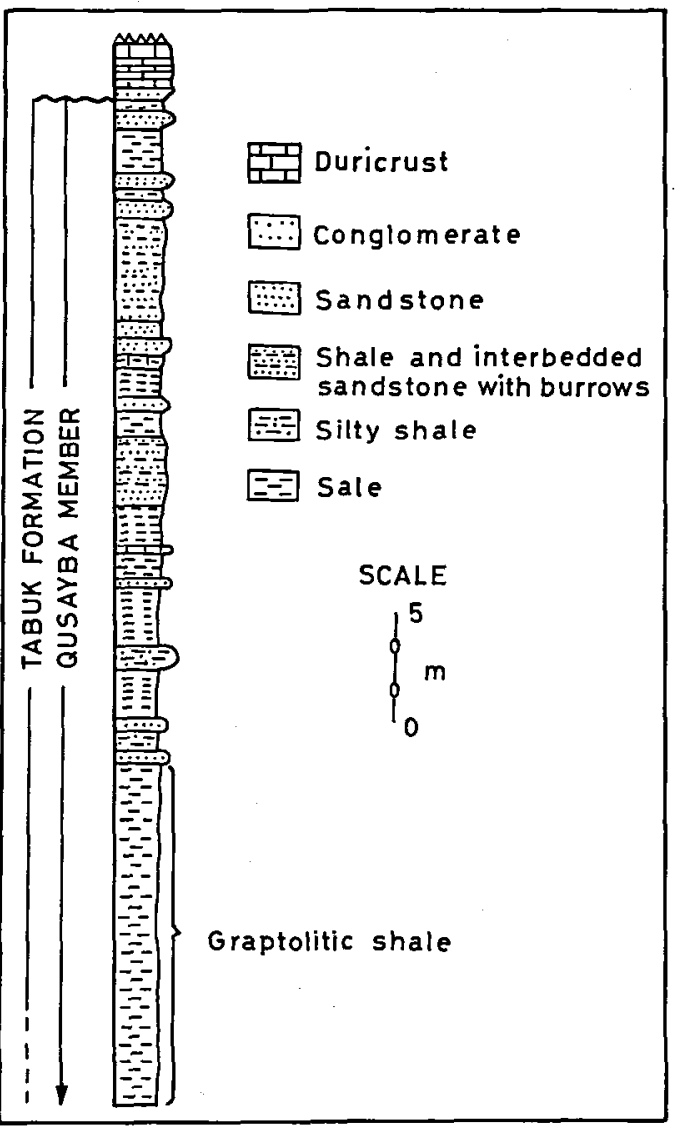

Fig. 2. Stratigraphic section of the Qusayba Shale Member, Qusayba, Al Qasim Province, central Saudi Arabia.

caceous, with layers of light grey platy fine sandstone, with Climacograptus at several horizons.

The lower sediments represent a part of the Llandovery transgression which brought the graptolites with it. At higher levels, shallower environments existed where the sandstone and siltstone percentage increases. These beds vary in thickness from $0.3-0.8 \mathrm{~m}$, are rippled, and have a variety of vertical and horizontal burrows which indicate a very shallow marine environment.

\section{Faunal association}

Steineke et al. (1958) mentioned that probable Climacograptus and several other graptolites occur in beds about 375 metres below the top of the Tabuk Formation. Powers et al. (1966) reported that several samples collected from the Tabuk
Formation, but without specific locality information, were identified as definitely Silurian on the basis of contained Monograptus and some bivalves. They also mentioned the presence of Rastrites. Rickards and Koren' (1974) described Glyptograptus (Pseudoglyptograptus) tabukensis sp. nov. of convolutus Zone (Llandovery) age from a bore hole near Tabuk, Saudi Arabia. This species has not yet been found in the Qusayba Shale at Al Qusayba, Al-Qasim Province. Rickards (1976) mentioned the presence of Lagarograptus cf. tenuis from the convolutus Zone of the Tabuk Formation.

Thomas (1977) described a trilobite Platycoryphe dyaulax sp. nov. from the Qusayba shale. McClure (1978) reported that the Qusayba shales bear a rich graptolite fauna dated as lower Llandovery - convolutus Zone of the Aeronian Stage. $\mathrm{He}$ also mentioned the presence of a trilobite, and an abundant chitinozoan and acritarch assemblage, but he did not list these species. ElKhayal (1985) mentioned the presence of Monograptus ex gr. barrandei, $M$. convolutus, $M$. decipiens decipiens and $M$. elongatus from the $\mathrm{Qu}-$ sayba shale. The shales at Al Qusayba contain shelly forms, such as the bivalve cf. Nucleolites sp, a brachiopod cf. Eocoelia, an ostracode cf. Ctenobolbina, orthocones, indeterminate inarticulate brachiopods, conodonts and undetermined eurypterid fragments.

The graptolites include the following species collected from the lower part of the Qusayba shale at Qusayba: Climacograptus cf. rectangularis (McCoy, 1850), Climacograptus scalaris (Hisinger, (1837), Glyptograptus (Glyptograptus incertus (Elles \& Wood, 1907), Orthograptus cyperoides (Törnquist, 1897), Orthograptus insectiformis (Nicholson, 1869), Petalograptus minor (Elles, 1897), Petalograptus ovatoelongatus (Kurck, 1882), Retiolites perlatus perlatus (Nicholsen, 1886), Pristiograptus regularis regularis (Törnquist, 1899), Lagarograptus cf. tenuis (Portlock, 1843), Monograptus ex gr. barrandei (sensu, Elles \& Wood, 1913), Monograptus convolutus (Hisinger, 1837), Monograptus decipiens decipiens (Törnquist, 1899) and Monograptus elongatus (Törnquist, 1899). (See pl. 1 \& 2).

These species indicate the convolutus Zone (Llandovery). This Zone was defined by Marr and Nicholson (1888) in a mixed shelly and grap̀tolite sequence of zones from the Lake District's 


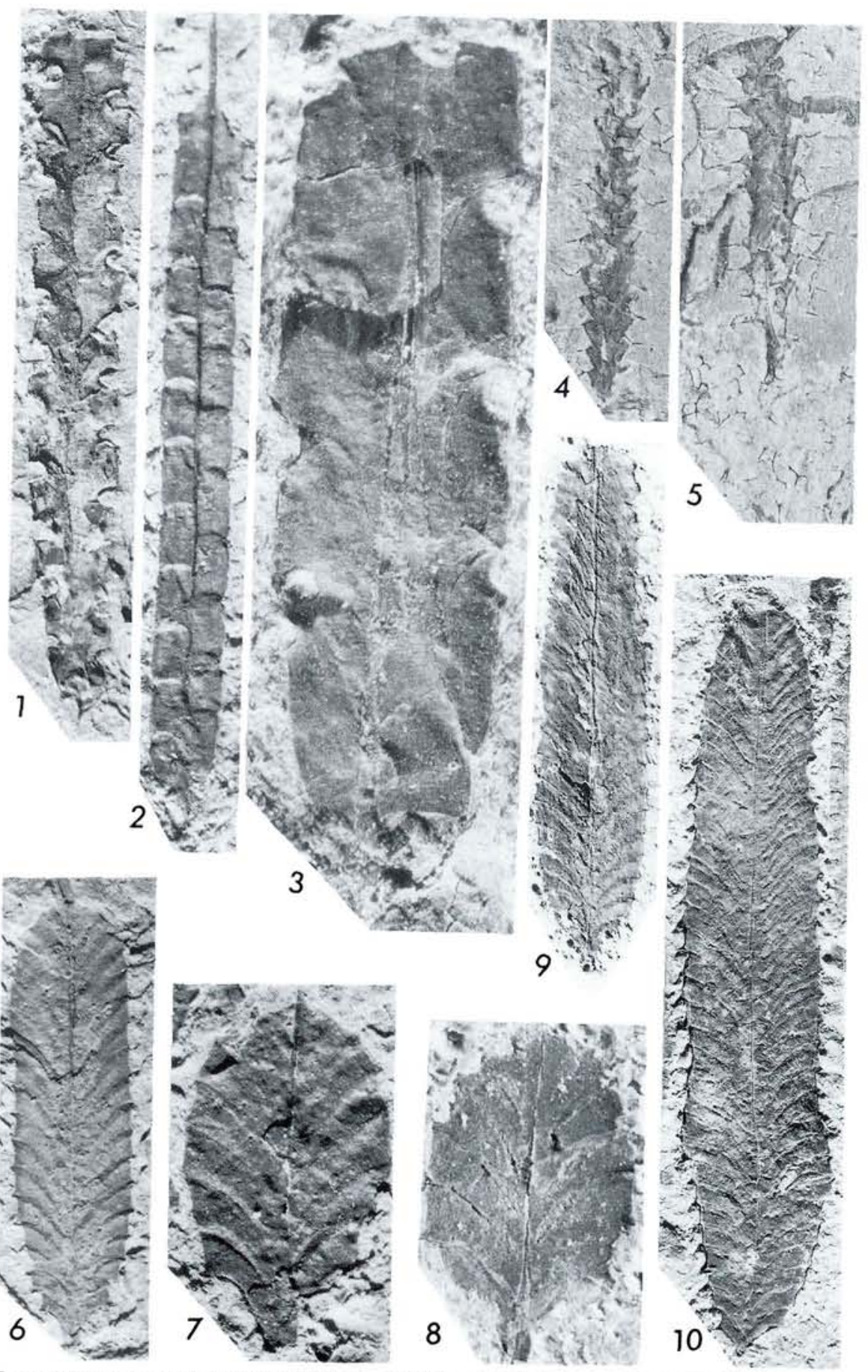

Fig. 1. Climacograptus cf. rectangularis McCoy, 1850. Complete rhabdosome (KSU.STQ 208). ×10.

Fig. 2. Climacographus scalaris Hisinger, 1837. Complete rhabdosome (KSU.STQ 25 C1). $\times 10$.

Fig. 3. Glyptograptus (G.) incertus Elles \& Wood, 1907 Enlarged photograph (KSU.STQ 87 C3). $\times 30$.

Figs 45. Othograptus insectiformis Nicholson, 1896. 4: Complete rhabdosome (KSU.STQ 109 O1). ×6. 5: Rhabdosome showing thecal spines and strongly divided virgella (KSU.STQ 103 O1). $\times 6$.

Figs 6, 9-10. Petalograptus ovatoelongatus Kurck, 1882. 6: Obverse view (KSU.STQ 165). ×5.9: Intermediate form (KSU.STQ 174). $\times 4$. 10: Mature specimens (KSU.STQ 128b P5), $\times 4$.

Figs 7-8. Petalograptus minor Elles, 1897. 7: Obverse view (KSU.STQ 165a P2). ×10. 8: Another rhabdosome, showing the sicula (KSU.STQ 74). $\times 10$. 
Skellgill section. Hutt (1974) revised the section and recorded 32 species of graptolites, while Rickards (1976a) recorded the presence of 42 graptolite species from the convolutus Zone in the British Isles.

The Qusayba section yielded only 14 species of graptolites. Future research could prove the presence of more species. The Qusayba graptolites constituted about one third of the species found in the British Isles.

The convolutus Zone is recognizable throughout the world; the British Isles (Hutt, 1974), Poland (Teller, 1969), Alaska (Churkin \& Carter, 1970), the U.S.S.R. (Obut et al. 1965), Malaya (Jones, 1973), Germany (Stein, 1965), Morocco (Willefert, 1963).

\section{Palaeontological comments}

Specimens similar to Climacograptus rectangularis are associated with $C$. scalaris. The Arabian forms differ from $C$. rectangularis in the width of the rhabdosome, which does not exceed $1.2 \mathrm{~mm}$ compared to $2 \mathrm{~mm}$ in $C$. rectangularis McCoy (sensu, Elles \& Wood, 1906, p. 187). (Plate 1, Fig. 1). Forms which are close to Elles and Wood's concept of Climacograptus scalaris occur, but differ in the spacing of the thecae and the nature of the apertural margin. (Plate 1, Fig. 2).

The Qusayba Shale contains specimens of Glyptograptus (G.) incertus. The Arabian forms have a smaller proximal width $(1.0 \mathrm{~mm})$ than those of Elles \& Wood. Hutt (1974) recorded this species from the convolutus and sedgwickii zones of the Lake District. (Plate 1, Fig. 3).

Specimens of Petalograptus minor in association with $P$. ovatoelongatus are present in the $\mathrm{Qu}-$ sayba shale. (See plate 1, Figs 7-8). I found it difficult to distinguish apparent $P$. minor from early growth stages of $P$. ovatoelongatus. A continuous variation in width at th $4^{1}$ of $2.4-4.2 \mathrm{~mm}$ has been observed, while the length range is $3.6-7.7 \mathrm{~mm}$. The sicula is $1.8 \mathrm{~mm}$ long, similar to that of $P$. ovatoelongatus. Hutt (1974) also had difficulty in distinguishing $P$. minor from early growth stages of other petalograptids especially $P$. ovatoelongatus. I agree with Hutt that examination of further specimens may show that $P$. minor is an early growth stage of $P$. ovatoelongatus.
The Arabian specimens of Petalograptus ovatoelongatus agree well with Bouček and Přibyl's (1941) dimensions of the species, but most of them do not show the ovato-elongate outline of Kurck's original specimen. Elles and Wood (1908) considered the ovato-elongate character of specific importance. The rhabdosome width in the Qusayba forms ranges from $3.5-5.3 \mathrm{~mm}$ at th $8^{1}$ for specimens ranging in length from 13-26.5 $\mathrm{mm}$ and a sicula not more that $1.8 \mathrm{~mm}$ long. (Plate 1, Figs 6, 4-10). El-Khayal (1986) have noted that both $P$. ovatoelongatus and $P$. minor may be conspecific with $P$. palmeus Barrande.

Rickards et al. (1977) noted that $P$. ovatoelongatus ranges from the triangulatus to the lower part of the convolutus zones.

Hutt (1974) described Orthograpatus cyperoides (Tornquist, 1897) from the convolutus Zone in the Lake District. The Qusayba material agrees well with Törnquist's figures and with Elles \& Wood's (1907), Rickards's (1970) and Hutt's description and figures. The latter author reported the presence of apertural spines on specimens assigned to $O$. cyperoides. I agree with Hutt that $O$. cyperoides may be conspecific with the spiny $O$. insectiformis. Both species are always present together on the same slabs in the Qusayba section. It is possible that the spines were so delicate that they were easily broken and did not preserve well on some specimens.

The Arabian specimens of Orthograpatus insectiformis compare with Nicholson's (1869) figure and Hutt's (1974) description of the species. Churkin and Carter (1970) recognized the presence of paired apertural spines, while Hutt (1974) noticed the presence of a strongly divided virgella. Both features are also present in the Arabian forms. (Plate 1, Figs 4,5). The species is recorded from the U.K. (Nicholson, 1869; Lapworth, 1876; Elles and Wood, 1907; Rickards \& Koren, 1974 and Hutt, 1974), Morocco (WaterIot, 1945), U.S.S.R. (Obut et al., 1968), Alaska (Churkin and Carter, 1970) and Australia (Thomas, 1960). (Plate 1, Figs 4,5).

The Arabian material fits Nicholson's (1868) description of Retiolites perlatus the species which Bouček and Münch (1944) made the type of their subgenus Pseudoretiolites. The Qusayba specimens have thecae numbering $9-10 \mathrm{~mm}$. Elles \& Wood (1908) gave higher thecal counts, 


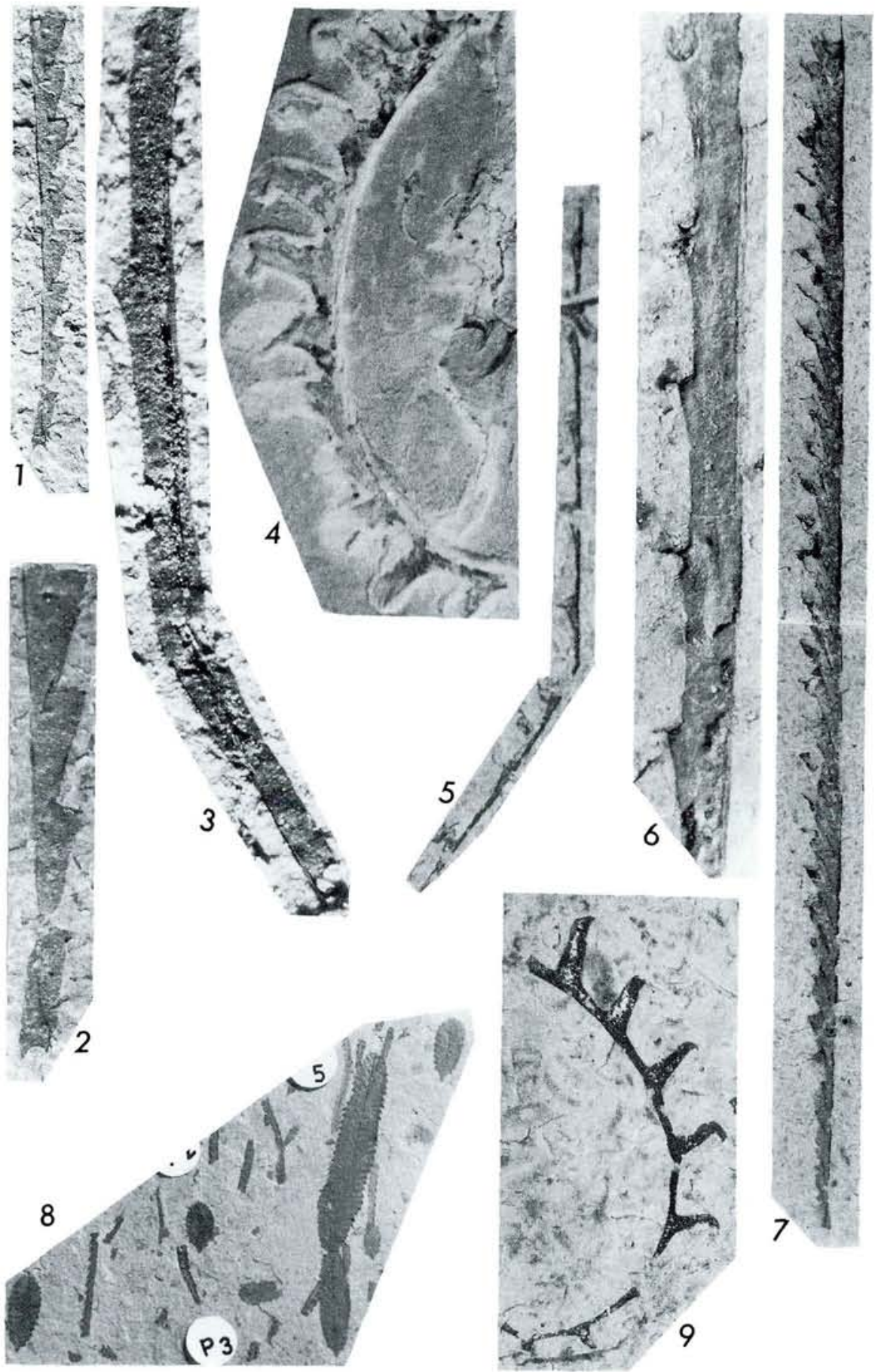

Figs 1-2,7. Pristiograptus regularis regularis Törnquist, 1899. 1: Proximal fragment showing sicula (KSU.STQ 89P). $\times 10.2$ : Same specimen as in fig. 1 enlarged showing the sicula and four thecae, $\times 20.7$ : A longer rhabdosome with sicula (KSU.STQ 144P). $\times 6$. Figs 3,6. Lagarograptus cf. tenuis Portlock, 1843. 3: Proximal fragment showing sicula and three thecae (KSU.STQ 229). $\times 25.6$ : Well preserved fragment showing the triangular apertural process (KSU.STQ 109a), $\times 18$.

Fig. 4. Monograptus convolutus Hisinger, 1837. Fragment of a rhabdosome (KSU.STQ 94). $\times 10$.

Fig. 5. Monograptus elongatus Törnquist, 1899. Part of a rhabdosome showing the elongated thecae (KSU.STQ $89 \mathrm{me}$ ). $\times 6$.

Fig. 8. A photograph of a slab from the Qusayba shale with $P$. minor, P. ovatoelongatus, C. scalaris and a fragment of $P r$. regularis regularis (KSU.STQ 128B). c. $\times 1.3$.

Fig. 9. Monograptus decipiens decipiens Törnquist, 1899 showing a proximal fragment (KSU.STQ 94 Md). $\times 10$.

N.B.: $K S U=$ King Saud Univ., $S=$ Silurian, $T=$ Tabuk, $Q=$ Qusayba. All specimens are kept in the Geology Dept. Collection, King Saud Univ. Riyadh, Saudi Arabia. 
16-12 in $10 \mathrm{~mm}$, while Hutt (1974) mentioned that the type specimen has a spacing 7.5 in $10 \mathrm{~mm}$ proximally to 9 in $10 \mathrm{~mm}$ distally.

The specimens of Pristiograptus regularis regularis conform to Törnquist's (1899) illustrations and to Elles \& Wood's (1911) description. The type Scanian specimens, however, have a slightly longer sicula $(1.0 \mathrm{~mm})$ than the Arabian material (0.80 mm).

Rickards (1976b) mentioned the presence of $M$. cf. tenuis from the convolutus Zone of the Tabuk Formation, and noticed that the Arabian forms display a genicular hood and occasionally, apertural process. The Arabian forms of Lagarograptus cf. tenuis shares with Lagarograpatus tenuis (Portlock) and Lagarograptus inexpeditus Obut and Sobolevskaya (1968), the semicircular, thecal excavation, the geniculum, triangular ventral apertural process, subparallel dorsal and ventral rhabdosomal walls and generally the thecal count. The Qusayba specimens differ from $L$. tenuis and $L$. inexpeditus in the level to which the sicular apex reaches. In the Arabian forms the apex reaches a little higher than th2 aperture. The sicular apex reaches about halfway between the aperture of th1 and th 2 in L. tenuis (Hutt, 1968) and about the level of the aperture of th1 in L. inexpeditus according to Rickards (1976b). The specimens figured and described by Hutt (1975) as $L$. acinaces have a longer sicula and a much longer first theca $(3.2 \mathrm{~mm})$. (Plate 2, Figs 3 \& 6). El-Khayal (1987, in press) restudied the specimens of Lagarograptus collected from the Qusayba Shale and came to the conclusion that the Arabian specimens belong to a new species.

The Arabian specimens of Monograptus ex gr. barrandei compare well with figures given by Elles \& Wood (1913). Bouček \& Přibyl (1952) discussed this species and mentioned that the original specimens of $M$. barrandei are lost and they rejected the figured British specimens from the synonymy but did not rename them. Earlier Přibyl (1948) had accepted Elles \& Wood's figures as $M$. barrandei.

Monograptus convolutus was discussed at length by Prribyl and Münch (1942). It is a common species in the Qusayba shale. The specimens match Hisinger's figure and Sudbury's (1958) description. $M$. convolutus in widely distributed. It has been recorded from Europe (Hisinger, 1837; Carruthers, 1868; Törnquist, 1892; Perner, 1897;
Eisel, 1912; and many others), the British Isles (Elles \& Wood, 1913; Rickards, 1970; Hutt, 1975), North Africa (Waterlot, 1945 and Willefert, 1963), Canada (Lenz, 1982), the U.S.S.R. (Obut \& Sobolevskaya, 1967; Koren' \& Enokyan, 1970).

Specimens identified as Monograptus decipiens desipiens match the descriptions of Törnquist (1899), Sudbury (1958), Rickards (1970) and Hutt (1975). Complete specimens were not found. This is the first time that $M$. decipiens decipiens has been recorded from Saudi Arabia. This species has been recorded from Sweden (Törnquist, 1899); the British Isles (Elles \& Wood, 1913; Sudbury, 1958; Rickards, 1970 and Hutt, 1975), the U.S.S.R. (Chaletskaya, 1962; Nikiforova \& Obut, 1965) and Canada (Lenz, 1982).

Přibyl (1945) discussed $M$. elongatus (Törnquist, 1899) and later (Přibyl, 1948) as proposed by Gortani (1923) put it into synonymy with $M$. intermedius Carruthers. Strachan (1969), however, redescribed Carruthers' type graptolites and showed that $M$. elongatus Törnquist is not a junior synonym of $M$. intermedius Carruthers. The Qusayba specimens of $M$. elongatus agree well with figures given by Törnquist (1899). (Plate 2, Fig. 5).

Acknowledgements. The author wishes to thank King Saud University, Riyadh, Saudi Arabia for financial support, Dr. Mike Romano, Sheffield University for reading the manuscript, and also to Dr. R. B. Rickards who invited me to compare material housed in the Sedgwick Museum.

\section{Dansk sammendrag}

Graptolitter fra Qusayba skifferen i Al-Qasim provinsen i Saudi Arabien indicerer at alderen er Llandovery. Nogle af arterne er fundet for første gang i denne region og kan bestemmes til former fra britiske og bøhmiske aflejringer. Artssammensætningen peger på convolutus Zonen og omfatter Climacograptus cf. rectangularis, C. scalaris, Glyptograptus (G.) incertus, Orthograptus cyperoides, $O$. insectiformis, Petalograptus minor, $P$. ovatoelongatus, Retiolites perlatus perlatus, Pristiograptus regularis regularis, Lagarograptus cf. tenuis, Monograptus ex gr. barrandei, $M$. convolutus, $M$. decipiens decipiens og $M$. elongatus.

\section{References}

Bouček, B. \& Münch, A. 1944: Retioliti strědoevropskeho Llandovery a spodníto Wenlocku. Rozpr. Ceské Akad. Věd Uměni, Prague, 53 (41): 1-50. Die Retioliten des mit- 
teleuropäischen Llandovery und unteren Wenlock. Bull. int. Acad. tchéque Sci., 44, 527-580, (in German).

Bouĉek, B. \& Přibyl, A. 1941: Über Petalolithen aus der Gruppe $P$. folium (His.) und über Cephalograptus Hopk. Rozpr zeské Acad. Véd Umèni. 52, 1-22.

Bouček, B. \& Príibyl, A. 1952: On some slender species of the genus Monograptus Geinitz, especially of the subgenera Mediograptus and Globosograptus. Bull. int. Acad. tchéque Sci., Prague 52, 185-216.

Bramkamp, R. A., Ramirez, L. F., Brown, G. F. \& Pocock, A. E. 1963: Geology of the Wadi ar Rimah Quadrangle, Kingdom of Saudi Arabia. U.S. Geol. Survey Mics. Geol. Invest. map 1-206 A.

Carruthers, W. 1867: Graptolites: their structure and systematic position. Intell. Observer. 11 (4), (64), 283-292: (5), (65), 365-374.

Carruthers, W. 1868: A revision of the British graptolites, with description of new species and notes on their affinities. Geol Mag., (1), 5, 64-74, 125-133.

Chaletskaya, O. N. 1962: [Graptolites from the Llandovery of Western Tien-Shan.] In: Stratigrafiya y Paleontologiya Uzbekistana y sopredelnich rainonov. Inst. Geol. AN Uz. SSR. Tashkent, (in Russian).

Churkin, M. Jr. \& Carter, C. 1970: Early Silurian graptolites from southeastern Alaska and their correlation with graptolite sequences in North America and the Arctic. Prof. Pap. U.S. Geol. Surv. (653), 1-51.

Eisel, R. 1912: Über zonenweise Entwicklung der Rastriten und Demirastriten. Jber. Ges. Freunden Naturw. Gera, $53 / 54,27-43$.

El-Khayal, A. A. 1985: Some Silurian (Llandovery) monograptids from Saudi Arabia. Scipra Geol. 80, 15-22.

El-Khayal, A. A. 1986: Petalograptus palmeus Barrande from the Qusayba Shale (Llandovery, Silurian) of Saudi Arabia. J. Coll. Sci., King Saud Univ., Riyadh. 17 (2), pp. 189 206.

El-Khayal, A. A. 1987: Lagarograptus rickardsi sp. Nov. from the Silurian (Llandovery) of Saudi Arabia. J. Coll. Sci., King Saud Univ., Riyadh. 18 (in press).

El-Khayal, A. A. \& Romano, M. 1985: Lower Ordovician trilobites from the Hanadir shale of Saudi Arabia. Palaeontology. 28 (2), 401-412.

Elles, G. L. 1897: The subgenera Petalograptus and Cephalograptus. Q. Jl. Geol. Soc. Lond., 53, 186-212.

Elles, G. L. \& Wood, E. M. R. A monograph of British Grapatolites. Edited by C. Lapworth. Palaeontogr. Soc. (Monogr.): (5), 1906, Ixxiii-xcvi, 181-216; (6) 1907, xcviicxx, 217-272; (7), 1908, cxxi-cxIviii, 273-358, (8) 1911, $359-414$; (9) 1913, 415-486.

Fairbridge, R. W. 1970: South Pole reaches the Sahara. Science. 168, 878-881.

Fortey, R. A. \& Morris, S. F. 1982: The Ordovician trilobite Neseuretus from Saudi Arabia, and the palaeogeography of the Neseuretus fauna related to Gondwanaland in the earlier Ordovician. Bull. Br. Mus. Nat. Hist. (Geol.). 36 (2), 63-75.

Gortani, M. 1923: Contribuzioni allo studio del Paleozoico Carnico. Pt. 6, Faune a Graptoliti. Palaeontogr. ital. 26 (for 1920), 1-56.

Hisinger, H. 1837: Lethaea Suecica seu Petrifacta Suecica. Supplementum 1. $124 \mathrm{pp}$, Stockholm.

Hutt, J. E. 1968: A redescription of the Llandoverian monograptid "Graptolithus" tenuis, Portlock, 1843. Geol. Mag., 105, 251-255.

Hutt, J. E. 1974: The Llandovery grapatolites of the English Lake District. Palaeontogr. Soc. (Monogr.). (1), 1-56.

Hutt, J. E. 1975: The Llandovery graptolites of the English Lake District. (2), Palaeontogr. Soc. (Monogr.), London, 57-137.
Jones, C. R. 1973: The Siluro-Devonian graptolite faunas of the Malay Peninsula. I.G.S. Overseas Geology and Mineral Resources. 44, 1.

Koren', T. N. \& Enokyan, V. S. 1970: (Siluriiskie i nizhnedevonskie otlozheniya severo-zapadnoi chasti yugorskogo poluostrovov i ostrovov pechorskogo morya.) NIIGA uchenye zapiski. Paleont. i biostrat. 30, 5-25, (in Russian).

Lapworth, C. 1876: On Scottish Monograptidae. Geol. Mag. (2), 3, 544-552.

Lenz, A. C. 1982: Llandoverian graptolites of the Northern Canadian Cordillera: Petalograptus, Cephalograptus, Rhaphidograptus, Dimorphograptus, Retiolitidae and Monograptidae. Life Sci. Contr. Royal Ontario Museum, 130, 154 pp.

Marr, J. E. \& Nicholson, H. A, 1888: The Stockdale Shales. $Q$. Jl. geol. Soc. Lond. 44, 654-732.

McClure, H. A. 1978: Early Palaeozoic glaciation in Arabia. Palaeogeogr. Palaeoclimatol. Palaeoecol. 25, 315-326.

McCoy, F. 1851: In Sedgwick, A. \& McCoy, F. 1851-55. A synopsis of the British Palaeozoic fossils in the geological museum of the university of Cambridge. (1) 1851, i-iv, 1-184; (2), 1852, i-viii, 185-406, (3), 1855, i-xcviii, 407-661, London \& Cambridge.

Nicholson, H. A. 1868: On the graptolites of the Coniston Flags; with notes on the British species of the genus Graptolites. Q. Jl. geol. Soc. Lond., 24, 521-545.

Nicholson, H. A. 1869: On some new species of graptolites. Ann. Mag. nat. Hist. (4), 4, 231-242.

Nikiforova, O. I. \& Obut, A. M. 1965: (Siluriiskaya sistema.) Stratigrafiya SSSR. 4, 531 pp. Moscow.

Obut, A. M. \& Sobolevskaya, R. F. 1967: In Obut, A. M., Sobolevskaya, R. F. \& Nikolaev, A. A. (Graptolity $i$ stratigrafiya nizhnego silura okrainnykh podnyatti Kolymskogo Massiva (Severo-vostok SSSR.) Akad. Nauk SSSR. Sibirsk. otdel. Inst. Geol. Geofiz. 162 pp, (in Russian).

Obut, A. M., Sobolevskaya, R. F. \& Bondarev, V. I. 1965: (Graptolity silura Taimyra.) Akad. Nauk SSSR. Sibirsk. otdel. Inst. Geol. Geofiz. 120 pp, (in Russian).

Obut, A. M., Sobolevskaya, R. F. \& Merkuryeva, A. P. 1968: (Graptolity llandoveri v kernakh burovykh skvazhin noryl' skogo rayona.) Akad. Nauk SSSR. Sibirsk. otdel. Inst. Geol. Geofiz. 136 pp, (in Russian).

Perner, J. 1897: Etudes sur les graptolithes de Bohême. Prague. (3a), 1-25.

Powers, R. W., Ramirez, L. F., Redmond, C. D. \& Elberg, E. L. Jr. 1966: Geology of the Arabian Peninsula (sedimentary geology of Saudi Arabia). U.S. Geol. Surv., prof. Pap.: 560-D, 1-147.

Pribyl, A. 1945: The Middle-European monograptids of the genus Spirograptus Gürich. Bull. int. Acad. tchéque Sci. 45, 185-231; Rozpr. ceské Akad. 54 (19), 1-46, (in Czech).

Pribyl, A. 1948: Bibliographic Index of Bohemian Silurian graptolites. Knih. st. geol. Úst čsl Repub., 22, 1-96.

Přibyl, A. \& Münch, A. 1942: Revise středoevropoských zástupcul rodu Demirastrites Eisel. Rozpr. české Akad. Véd Uměni, Prague, 51, (31), 1-30.

Rickards, R. B. 1970: The Llandovery (Silurian) graptolites of the Howgill Fells, Northern England. Palaeontogr. Soc. (Monogr.), 1-108.

Rickards, R. B. 1976a: The sequence of Silurian graptolite zones in the British Isles. Geol. J., 11, (2), 153-188.

Rickards, R. B. 1976b: Classification of Monograptus: a redefinition of some Llandovery graptolite genera. II Soviet Graptolite Colloquium (Tallin), 155-162.

Rickards, R. B., Hutt, J. E. \& Berry, W. B. N. 1977; Evolution of the Silurian and Devonian Graptoloids. Bull. Br. Mus. nat. Hist. (Geol.). 23 (1), 1-120.

Rickards, R. B. \& Koren', T. N. 1974: Virgellar meshworks 
and sicular spinosity in Llandovery graptoloids. Geol. Mag. 111, 193-204.

Stein, V. 1965: Stratigraphische und paläontologische Untersuchungen im Silur des Frankenwaldes. Neues Jb. Geol. Paläont. Abh. 121, 111-200.

Steineke, M., Bramkamp, R. A. \& Sander, N. J. 1958: Stratigraphic relations of Arabian Jurassic oil. Amer. Assoc. Petrol. Geol. Tulsa: 1294-1329.

Strachan, I. 1969: A redescription of W. Carruthers' type graptolites. Bull. Br. Mus. nat. Hist. (Geol.). 17 (4), 183-206.

Sudbury, M. 1958: Triangulate monograptids from the Monograptus gregarius Zone (Lower Llandovery) of the Rheidol Gorge (Cardiganshire). Phil. Trans. R. Soc., (B). 241, 485-555.

Teller, L. 1969: The Silurian biostratigraphy of Poland based on graptolites. Acta geol. Pol., Warsaw, 19, 393-501.

Thomas, A. T. 1977: Classification and phylogeny of homalonotid trilobites. Palacontology, 20, 159-178.
Thomas, D. E. 1960: The zonal distribution of Australian graptolites. Jl. Proc. R. Soc. N.S.W. 94, 1-58.

Törnquist, S. L. 1892: Undersökningar öfver Siljansområdets graptoliter, Pt. 2. Acta Univ. lund. 28, 1-47.

Törnquist, S. L. 1897: On the Diplograptidae and Heteroprionidae of the Scanian Rastrites Beds. Acta Univ. lund. 33, 1-24.

Törnquist, S. L. 1899: Researches into the Monograptidae of the Scanian Rastrites beds. Acta Univ. lund. 35 (1), 1-25.

Waterlot, G. 1945: Les graptolithes du Maroc; premiere partie; généralitiés sur les graptolithes. Notes \& Mém Serv. Mines Carte géol. Maroc, (63), 1-112.

Willefert, S. 1963: Les graptolites du Silurian inférieur du jbel Eguer-Iguiguena (SW D'Ito, anticlinorium de Kasba-Tadla - Azrou, Maroc central). Notes \& Mém. Serv. Mines Carte géol. Maroc. (177), 1-74. 